\title{
LCA of the timber sector in Ghana: preliminary life cycle impact assessment (LCIA)
}

\author{
John Frank Eshun • José Potting • Rik Leemans
}

Received: 9 March 2011 / Accepted: 25 May 2011 / Published online: 7 June 2011

(C) The Author(s) 2011. This article is published with open access at Springerlink.com

\begin{abstract}
Purpose Most life cycle impact assessment (LCIA) approaches in life cycle assessment (LCA) are developed for western countries. Their LCIA approaches and characterization methodologies for different impact categories may not be necessarily relevant to African environmental conditions and particularly not for the timber sector in Ghana. This study reviews the relevance of existing impact categories and LCIA approaches, and uses the most relevant for the timber sector of Ghana.

Materials and methods The study reviewed 23 life cycle inventories (LCIs) and LCAs on forestry, timber, and wood products for relevant impact categories and LCIA approaches for their relevance to the specific conditions in Ghana. This study uses an earlier LCI study of the timber industry as a starting point for an additional LCIA. We next performed a correlation and regression analysis to learn whether wood wastes may function as a reasonable single indicator for land use as proxy for biodiversity loss and the other impact categories.

Results and discussion The literature review shows that no LCI or LCA studies were developed for Africa or the tropics. The LCIA approaches in the reviewed LCAs are indeed shown to take their basis in the environmental problems in western countries and characterization methodologies relating to how these problems manifest themselves in the western world. Characterization methodologies for different impact categories in CML-2000 and other LCIA approaches may not be necessarily relevant to African tropical environmental conditions and particularly not for the timber
\end{abstract}

J. F. Eshun $(\bowtie) \cdot$ J. Potting $\cdot$ R. Leemans Environmental Systems Analysis Group, Wageningen University, P.O. Box 47, 6708 PB Wageningen, The Netherlands e-mail: John.Eshun@wur.nl sector in Ghana. This situation hampers the reliability of our LCIA and points to a serious research gap in LCIA development in general.

We applied the scientifically well-recognized CML 2000 to the earlier LCI results and characterized the preliminary selected impact categories of global warming, acidification, eutrophication, photochemical oxidant formation, and human toxicity. The correlation analysis indicated that wood waste is indeed strongly correlated with land use as proxy for biodiversity loss and also positively correlated with the other five potential impact results. It can be concluded that wood waste production is a major driving force for biodiversity loss and a sufficiently good single indicator for all other environmental performance indicators in the timber sector of Ghana.

Conclusions This study and the previous LCI paper are pioneering a field not yet explored, since the correct environmental performance indicators are not yet developed or adapted to tropical conditions. The development of LCIA approaches in the tropics may be the start of a never-ending journey in LCA research in Africa, particularly Ghana.

Keywords Ghanaian timber sector- Environmental performance indicators - Functional units - Life cycle impact assessment (LCIA) · Tropical wood

\section{Introduction}

Eshun et al. (2010) compiled a comprehensive life cycle inventory (LCI) for the timber sector of Ghana. This LCI quantified the use of land, material, and energy resources as well as emissions and wastes for five major products (i.e., air-dried lumber, kiln-dried lumber, plywood, veneer, and 
furniture parts). Their results indicated that land-use change for timber production from 2000 to 2007 in Ghana is $34.0 \times$ $10^{3}$ ha per year. At this rate, Ghana will be completely deforested by 2025 . The total energy consumed by the timber sector was estimated at $1.9 \times 10^{9} \mathrm{MJ}$ per year with a related $\mathrm{CO}_{2}$ emission of 0.7 million tons per year, dominating overall greenhouse gas emissions of $\mathrm{CO}_{2}, \mathrm{CH}_{4}$, and $\mathrm{N}_{2} \mathrm{O}$. The timber industry generates 0.8 million $\mathrm{m}^{3}$ wood waste per year, which constituted $62 \%$ of the initial wood input to the timber industry, and contributed enormously to the rapid depletion of the country's timber resources (Eshun et al. 2010).

The five products in the LCI of Eshun et al. (2010) were further compared for three different functional units (cubic meters, kilograms, or Euros). The usual functional unit of $1 \mathrm{~m}^{3}$ of product produced was expected to insufficiently express the different services provided by the five products. We therefore selected two additional functional units. One defined as $1 \mathrm{~kg}$ of product produced and the other as $1 €$ of product produced. The chosen functional unit shows to influence on the inventory results and therewith plays a crucial role in the environmental comparison of production lines in Ghana's timber sector. The money-based functional unit, which also seems most appropriate as a measure for the function of the different timber products considered, favors the value-added products. Value-added products with strict forestry management practice hold a promising future for the sustainability of this sector (Eshun et al. 2010).

Only the interactions between economic processes and the environment were quantified by Eshun et al. (2010), but they did not yet estimate environmental performance indicators. This can be done by a formal LCIA that interprets the earlier LCI results in terms of potential impacts. Applying an LCIA to LCI results, i.e., performing a complete life cycle assessment (LCA), will help the industry to prioritize areas for environmental action and, at the same time, get the best return on their investments by reducing their operational environmental impact (Berkhout 1995; Daniel and Pappis 2008).

Most LCIA approaches in LCA are developed for western countries. Their specific environmental problems have become the "standard list" of impact categories included in most LCAs. Also, the methodologies for characterizing those potential impacts are based on how these problems manifest themselves in the western world (SETAC 1994; Alsema 2000; Tukker 2000; Brentrup et al. 2004; Pennington et al. 2004a). The "standard problem list" and the characterization methodologies for different impact categories may not be necessarily relevant to African environmental conditions and particularly not for the timber sector in Ghana. An evaluation of the relevance of existing LCIA approaches in LCA for the Ghanaian timber sector is urgently needed.
The objective of this paper is to review the relevance of different existing LCIA approaches, and to identify and apply the most relevant one to the LCI results of Eshun et al. (2010). We will thus use the most suitable approach to quantify major environmental performance indicators of the timber sector in Ghana. This study will provide a unique insight into the usefulness of different tools for evaluating environmental policies in Ghana and more generally in most of Africa.

\section{Materials and methods}

This study uses the LCI study of Eshun et al. (2010) as a starting point for an additional LCIA. LCIA is the third phase of an LCA study. LCIA aims at evaluating the significance of potential environmental impact of the results of inventory analysis (the second phase of an LCA), within the framework of the defined goal and scope of the study (first phase on an LCA; ISO - 14044 2006).

The LCIA phase consists of mandatory and optional steps. The mandatory steps of the LCIA approach are made up of the following: (1) the selection of impact categories, category indicators, and characterization methodology; (2) the assignment of LCI results to the selected impact categories (classification); and (3) the calculation of category indicator results (characterization). The additional optional steps of the LCIA approach consist of the following: (4) normalization, which expresses potential impacts in ways that can be compared; (5) grouping, i.e., sorting and possibly ranking of the impact categories; (6) weighting, i.e., converting and possibly aggregating indicator results across impact categories using numerical factors based on value-choices; and (7) data quality analysis, i.e., to better understand the reliability of the collection of indicator results and the LCIA profile.

The use of the optional steps depends on the goal and scope of the LCA studies because they are not allowed in comparative LCAs the results of which are to be disclosed to the public (ISO-14044 2006; ILCD 2010). The optional steps, and specifically the weighting step, have been criticized for their subjectivity. Goyal and Deshpande (2001) therefore argued, for example, to increase accuracy by defining clear and exhaustive criteria, based on experts' opinions, to specify the precise weights. We avoid in this study the optional steps and focus only on the mandatory steps in the LCIA phase.

The calculation of category indicators (i.e., mandatory step 3) becomes relevant once impact categories and their characterization methodology have been selected (i.e., mandatory step 1), and individual inventory data are assigned to the selected impact categories (i.e., mandatory step 2). The characterization methodology typically uses 
characterization factors. Characterization factors represent the potential of a single emission or resource consumption to contribute to a given impact category (ISO-14044 2006). Results for category indicators or potential environmental impacts are usually calculated by accumulating the products of the individual inventory data multiplied with its characterization factors for the given impact category as shown in Eq. 1:

Impact category indicator

$$
=\sum \text { Inventory data (II) } \cdot \mathrm{CF} \text { (II) }
$$

Where (II) stands for an individual inventory item. From the foregoing description of the LCIA phase, our study on Ghana's timber sector was performed in four steps:

1. Selection of relevant impact categories

An extensive literature search was carried out that yielded 23 life cycle studies on forestry, timber, and wood products in four journals (Table 1). For each of them, we identified the country where the study was performed, the content of the inventory analysis, whether an LCIA phase was included, and which impact categories then were used (see Table 1). This overview was used to arrive at the relevant selection of impact categories for extending the LCI of Eshun et al. (2010) with an LCIA into an LCA of the timber sector in Ghana.

2. Selection of relevant LCIA approach

This second step evaluated in more detail the approaches used in the LCIA phase. This evaluation was to ascertain the optimal relevance of LCIA approach used and the characterization methodology applied to the environmental impact assessment of timber sector in Ghana.

3. Application of selected LCIA approach to selected impact categories

The LCI results from Eshun et al. (2010) were then translated into potential environmental impacts with help of Eq. 1 for the selected relevant impact categories by using the selected LCIA approaches with its related characterization methodology (compliant with ISO-14044 (2006). LCIA results were calculated for the whole Ghanaian timber sector, as well as for the three functional units in Eshun et al. (2010; see Introduction).

4. Correlation analysis between different potential environmental impacts

We performed a correlation and regression analysis to learn whether wood wastes may function as a reasonable single indicator for land use as proxy for biodiversity loss and the other impact categories as well. This would enormously simplify a follow-up study in which we intend to explore environmental improvement options for economic activities in the timber sector in Ghana.

\section{Results}

\subsection{Selection of relevant impact categories}

This section reviews the 23 life cycle studies found on forestry, timber, and wood products (see Table 1). Ten studies stopped, similar as Eshun et al. (2010), at the inventory analysis phase. We call these, in accordance with common ISO-14044 terminology, LCI studies. The other 13 studies performed an additional LCIA and therewith comply with the definition of an LCA in ISO-14044 (2006).

Most of the LCI studies aimed to quantify energy demands and energy-related emissions. Six out of these ten LCI studies were conducted in the USA and four in Europe. None of the LCI studies specified why an additional LCIA phase was excluded. This could relate to the skeptical attitude of some LCA practitioners toward the LCIA phase. Also, the mandatory steps contain, in their opinion, inherent subjective value judgements (e.g., Barnthouse et al. 1997).

Most LCA practitioners regard LCIA as an essential phase in LCA. An LCI study only quantifies interactions between processes and the environment but does not assess the subsequent potential environmental impacts of these interactions. The information from LCI results therefore does not allow concluding on whether and to what extent a single inventory parameter contributes to the environmental problems. This bears the danger of picking single aspects of the inventory results and draw unsupported conclusions. A subsequent LCIA phase provides additional information about how harmful emissions are to the environment. ISO14044 (2006) clearly states that an LCA study without LCIA is not an LCA but just an LCI study.

Thirteen out of the 23 life cycle studies included an LCIA phase. Eleven of these LCA studies were conducted in Europe (see Table 1). Abiotic resources, biotic resources, and ecotoxicity impact categories were the least-studied categories in these studies. The most-studied impact categories were global warming, acidification, eutrophication, photochemical oxidant, and human toxicity. Interestingly, these impact categories coincide with the major Dutch and European environmental problems in the early days of LCA (NEPP 1989). The Dutch manual for LCA was the first that provided detailed guidance on LCA methodology (Guinée et al. 1993a, b). It defined the framework for all later methodological developments, 
Table 1 Overview of 23 life cycle studies on forestry, timber, and wood products in identified country where the study was performed, the content of the inventory analysis, whether an LCIA phase was included, and which impact categories used (x)

\begin{tabular}{|c|c|c|c|c|c|c|c|c|c|c|c|c|}
\hline \multirow[t]{2}{*}{ Product system } & \multirow[t]{2}{*}{ Country } & \multicolumn{10}{|c|}{ Environmental impact category used } & \multirow{2}{*}{$\begin{array}{l}\text { Content of the } \\
\text { LCI studied }\end{array}$} \\
\hline & & GW & OD & Ac & $\mathrm{Eu}$ & $\mathrm{PO}$ & $\mathrm{Et}$ & $\mathrm{Ht}$ & AR & $\mathrm{BR}$ & $\mathrm{EU}$ & \\
\hline $\begin{array}{l}\text { Forestry } \\
\text { (Michelsen et al. 2008) }\end{array}$ & Norway & $\mathrm{x}$ & & $\mathrm{x}$ & $\mathrm{x}$ & $\mathrm{x}$ & & $\mathrm{x}$ & & & & $\begin{array}{l}\text { Activity-related } \\
\text { emissions }\end{array}$ \\
\hline $\begin{array}{l}\text { Wood-based heating systems } \\
\text { (Solli et al. 2009) }\end{array}$ & Norway & $\mathrm{x}$ & & $\mathrm{x}$ & $\mathrm{x}$ & $\mathrm{x}$ & & $\mathrm{x}$ & & & $\mathrm{x}$ & $\begin{array}{l}\text { Energy-demand and } \\
\text { related emissions }\end{array}$ \\
\hline $\begin{array}{l}\text { Wood and other materials } \\
\text { (Petersen and Solberg 2005) }\end{array}$ & Norway/ Sweden & $\mathrm{x}$ & $\mathrm{x}$ & $\mathrm{x}$ & $\mathrm{x}$ & $\mathrm{x}$ & & $\mathrm{x}$ & & & $\mathrm{x}$ & $\begin{array}{l}\text { Energy-demand and } \\
\text { related emissions }\end{array}$ \\
\hline Forestry (Lindholm and Berg 2005) & Sweden & & & & & & & & & & & $\mathrm{CO}_{2}$-related emissions \\
\hline $\begin{array}{l}\text { Wood transport } \\
\text { (González-García et al. 2009b) }\end{array}$ & Sweden & $\mathrm{x}$ & & $\mathrm{x}$ & $\mathrm{x}$ & $\mathrm{x}$ & & & & & $\mathrm{x}$ & $\begin{array}{l}\text { Energy-demand and } \\
\text { related emissions }\end{array}$ \\
\hline $\begin{array}{l}\text { Forestry and pulpwood } \\
\text { (González-García et al. 2009a) }\end{array}$ & Sweden/Spain & $\mathrm{x}$ & & $\mathrm{x}$ & $\mathrm{x}$ & $\mathrm{x}$ & & & & & $\mathrm{x}$ & $\begin{array}{l}\text { Energy-demand and } \\
\text { related emissions }\end{array}$ \\
\hline $\begin{array}{l}\text { Wooden containers } \\
\text { (Gasol et al. 2008) }\end{array}$ & Spain & $\mathrm{x}$ & $\mathrm{x}$ & $\mathrm{x}$ & $\mathrm{x}$ & $\mathrm{x}$ & & $\mathrm{x}$ & $\mathrm{x}$ & $\mathrm{x}$ & $\mathrm{x}$ & $\begin{array}{l}\text { Material and energy- } \\
\text { related emissions }\end{array}$ \\
\hline $\begin{array}{l}\text { Hardboard } \\
\text { (González-García et al. 2009c) }\end{array}$ & Spain & $\mathrm{x}$ & $\mathrm{x}$ & $\mathrm{x}$ & $\mathrm{x}$ & $\mathrm{x}$ & $\mathrm{x}$ & $\mathrm{x}$ & $\mathrm{x}$ & & $\mathrm{x}$ & $\begin{array}{l}\text { Material and energy- } \\
\text { related emissions }\end{array}$ \\
\hline $\begin{array}{l}\text { Wood wastes } \\
\text { (Rivela et al. 2006b) }\end{array}$ & Spain & $\mathrm{x}$ & $\mathrm{x}$ & $\mathrm{x}$ & $\mathrm{x}$ & $\mathrm{x}$ & $\mathrm{x}$ & $\mathrm{x}$ & & $\mathrm{x}$ & $\mathrm{x}$ & $\begin{array}{l}\text { Wood waste-related } \\
\text { emissions }\end{array}$ \\
\hline $\begin{array}{l}\text { Particleboard } \\
\text { (Rivela et al. 2006a) }\end{array}$ & Spain & & & & & & & & & & & $\begin{array}{l}\text { Energy-demand and } \\
\text { related emissions }\end{array}$ \\
\hline $\begin{array}{l}\text { Medium density fibreboard } \\
\text { (Rivela et al. 2007) }\end{array}$ & Spain/Chile & & & & & & & & & & & $\begin{array}{l}\text { Energy-demand and } \\
\text { related emissions }\end{array}$ \\
\hline $\begin{array}{l}\text { Wood floor } \\
\text { (Nebel et al. 2006) }\end{array}$ & Germany & $\mathrm{x}$ & $\mathrm{x}$ & $\mathrm{x}$ & $\mathrm{x}$ & $\mathrm{x}$ & & & & & $\mathrm{x}$ & $\begin{array}{l}\text { Material and energy- } \\
\text { related emissions }\end{array}$ \\
\hline $\begin{array}{l}\text { Wood and packaging } \\
\text { materials (Hischier et al. 2005) }\end{array}$ & Switzerland & & & & & & & & & & & $\begin{array}{l}\text { Materials and energy- } \\
\text { related emissions }\end{array}$ \\
\hline $\begin{array}{l}\text { Waste wood } \\
\text { (Werner et al. 2007) }\end{array}$ & Europe & $\mathrm{x}$ & $\mathrm{x}$ & $\mathrm{x}$ & $\mathrm{x}$ & $\mathrm{x}$ & $\mathrm{x}$ & $\mathrm{x}$ & $\mathrm{x}$ & $\mathrm{x}$ & $\mathrm{x}$ & $\begin{array}{l}\text { Energy-demand and } \\
\text { related emissions }\end{array}$ \\
\hline $\begin{array}{l}\text { Wooden products } \\
\text { (Werner and Richter 2007) }\end{array}$ & $\begin{array}{l}\text { Europe, USA, } \\
\text { and Australia }\end{array}$ & $\mathrm{x}$ & $\mathrm{x}$ & $\mathrm{x}$ & $\mathrm{x}$ & $\mathrm{x}$ & & $\mathrm{x}$ & & & $\mathrm{x}$ & $\begin{array}{l}\text { Material and energy- } \\
\text { related emissions }\end{array}$ \\
\hline $\begin{array}{l}\text { Wood-fiber-reinforced } \\
\text { polypropylene composites } \\
\text { (Xu et al. 2008) }\end{array}$ & Australia & $\mathrm{x}$ & $\mathrm{x}$ & $\mathrm{x}$ & $\mathrm{x}$ & $\mathrm{x}$ & $\mathrm{x}$ & & & & $\mathrm{x}$ & $\begin{array}{l}\text { Energy-demand and } \\
\text { related emissions }\end{array}$ \\
\hline $\begin{array}{l}\text { Softwood lumber } \\
\text { production (Milota et al. 2005) }\end{array}$ & USA & & & & & & & & & & & $\begin{array}{l}\text { Energy-demand and } \\
\text { related emissions }\end{array}$ \\
\hline $\begin{array}{l}\text { Forestry } \\
\text { (Johnson et al. 2005) }\end{array}$ & USA & & & & & & & & & & & $\begin{array}{l}\text { Energy-demand and } \\
\text { related emissions }\end{array}$ \\
\hline $\begin{array}{l}\text { Forestry } \\
\text { (Aldentun 2002) }\end{array}$ & USA & & & & & & & & & & & $\begin{array}{l}\text { Energy-demand and } \\
\text { related emissions }\end{array}$ \\
\hline $\begin{array}{l}\text { Wood products (Puettmann } \\
\text { and Wilson 2005) }\end{array}$ & USA & & & & & & & & & & & $\begin{array}{l}\mathrm{CO}_{2} \text { and energy- } \\
\text { related emissions }\end{array}$ \\
\hline $\begin{array}{l}\text { Wood material } \\
\text { (Richter and Sell 1993) }\end{array}$ & USA & & & & & & & & & & & $\begin{array}{l}\text { Energy-demand and } \\
\text { related emissions }\end{array}$ \\
\hline $\begin{array}{l}\text { Softwood plywood } \\
\text { (Wilson and Sakimoto 2005) }\end{array}$ & USA & & & & & & & & & & & $\begin{array}{l}\mathrm{CO}_{2} \text { and energy- } \\
\text { related emissions }\end{array}$ \\
\hline Woody biomass (Khoo et al. 2008) & Singapore & $\mathrm{x}$ & & $\mathrm{x}$ & & $\mathrm{x}$ & & $\mathrm{x}$ & & & & $\mathrm{CO}_{2}$-related emissions \\
\hline
\end{tabular}

$G W$ global warming, $O D$ ozone layer depletion, $A c$ acidification, Eu eutrophication, $P O$ photochemical oxidant, Et ecotoxicity, $H T$ human toxicity, $E U$ energy use, $B R$ biotic resource depletion use, $A R$ abiotic resource depletion

including that for the LCIA phase. This is also recognizable in the impact assessment approaches used in the case studies in Table 1.
According to Pennington et al. (2004b), LCA practitioners often select impact categories based on the scope and goal definition of an LCA study. Unfortunately, the reviewed 
LCA studies did not argue why certain impact categories were selected and others were not. Moreover, none of the LCA studies discussed biodiversity loss and wood waste, which are major potential environmental impacts in Ghana's timber sector (Awanyo 2007). Possible reasons for this omission might be that characterizing biodiversity loss is at an early developmental phase (Udo de Haes et al. 2002; Dubreuil et al. 2007; Michelsen 2008) whereas waste is often considered as the remaining part of the technosphere and then not as an impact category in itself.

The reviewed list of impact categories provides representative information for LCI and LCA studies in the timber sector in general. Table 1 shows that no LCA studies were done in Africa or the tropics. There is thus a need to decide on a list of impact categories relevant for our LCA study in Ghana. According to ISO-14044 (2006), the list of selected impact categories has to comply with internationally accepted practice. Based on this and Table 1, the following impact categories were preliminary selected: global warming, acidification, eutrophication, photochemical oxidant formation, and human toxicity. We omitted ozone depletion and biotic resource use but added wood waste and biodiversity loss to this list. We limited the impact category abiotic resource use to energy use (though this and wood waste are basically inventory items). These categories were taken as starting points to address the major environmental problems of Ghana's timber sector.

\subsection{Selection of relevant LCIA approach}

This section continues with the 13 LCA and other studies not being strictly LCAs in Table 1 and closer looks into their LCIA phase. The LCA studies without any of the environmental impact categories express the environmental worries despite the reluctance towards impact assessment. Table 2 summarizes the overall LCIA approach used and the specific category indicator and characterization factors applied for separate impact categories.

Four LCIA approaches were identified: Environmental Design of Industrial Products-97 (EDIP-97), CML 2 baseline2000 (CML-2000), Eco-indicator 95, and Eco-indicator 99. EDIP-97, CML-2000, and Eco-indicator 95 follow a midpoint approach in LCIA. Mid-point approaches places the category indicators for environmental impact categories relatively close to environmental interventions and are based on established knowledge. The amount of subjectivity and uncertainty involved in a mid-point approach is therefore considered limited. However, the main disadvantage of this approach is that the results are sometimes hard to interpret across indicators. Additional subjective information is needed to for that. Eco-indicator 99 has an end-point approach to environmental impact assessment. End-point approach places indictors relatively close to the end-points, i.e., safeguarding issues such as human health, ecosystem quality, and resources. The end-point approach allows decision makers to easily interpret results, but its main disadvantage is the high level of uncertainty (Guinée et al. 2001). For example, Gasol et al. (2008) used CML-2000 approach instead of Eco-indicator 99 to avoid subjectivity of potential environmental impact results. This study will use a mid-point approach since its effects can be calculated with more certainty than the endpoint approach. As knowledge develops, the mid-point effects will move closer to the end of the cause-effect chain.

Three LCIA approaches (EDIP-97, CML-2000, and Ecoindicator 95) cover several impact categories for which characterization results are expressed in the same units. The documentation for those three approaches reveals that they basically use the same characterization methodology for global warming, ozone layer depletion, acidification, eutrophication, and photochemical oxidant. Characterization methodology for these impact categories follows a mid-point approach.

All four LCIA approaches differ for impact categories such as ecotoxicity and human toxicity (see Table 2). That is visible from the category indicators for ecotoxicity and human toxicity using different units across the different approaches. However, all models use a similar key-property approach in which the most important fate characteristics are included in a simple modular framework. This has the advantage that relatively few substance data for calculation of the characterization factors are required.

Some LCA studies from Table 2 combined characterization methodology in the followed LCIA approach with characterization methodology from other studies. That specifically applies to human toxicity where this combination of characterization methodologies enabled the study to determine toxicological impact results for substances covered in the additional characterization methodology used. Werner and Richter (2007), for example, combined CML-2000 and Eco-indicator 95, because CML-2000 does not include characterization factors for chemical components used in preserving materials in an adequate manner. Solli et al. (2009) in his LCA of wood-based heating systems in Norway employed CML-2000 approach for most selected impact categories. However, the characterization methodology for human toxicity combined Johansson et al. (2004) and Hertwich et al. (2006).

The land use impact category was only covered by Eco-indicator 99 (see Table 2). The other three LCIA approaches did not cover land use as an impact category. Land use is nowadays considered an inventory item contributing to the impact category biodiversity loss. There is no consensus yet on how to define its category indicator, i.e., how to characterize it (Udo de Haes et al. 2002; Michelsen 2008).

Solid waste impact category was only covered by EDIP-97 and Eco-indicator 95 (see Table 2). CML-2000 and Eco- 
Table 2 Evaluation of LCIA methods and characterization factors in LCA studies in the timber sector in Table 1

\begin{tabular}{|c|c|c|c|c|}
\hline Impact category & $\begin{array}{l}\text { EDIP-97 } \\
\text { (Wenzel } \\
\text { et al. 1997) }\end{array}$ & $\begin{array}{l}\text { CML baseline-2000 } \\
\text { (Guinée et al. 2000) }\end{array}$ & $\begin{array}{l}\text { Eco-indicator } \\
95 \text { (Goedkoop } \\
1995)\end{array}$ & $\begin{array}{l}\text { Eco-indicator } 99 \\
\text { (Goedkoop and } \\
\text { Spriensma 2000) }\end{array}$ \\
\hline $\begin{array}{l}\text { References of LCA studies } \\
\text { using the various LCIA } \\
\text { methodologies }\end{array}$ & (Khoo et al. 2008) & $\begin{array}{l}\text { (Petersen and Solberg 2005; Nebel et al. 2006; } \\
\text { Werner et al. 2007; Werner and Richter 2007; } \\
\text { Gasol et al. 2008; Michelsen et al. 2008; } \\
\text { González-García et al. 2009a; González- } \\
\text { García et al. 2009c; Solli et al. 2009) }\end{array}$ & $\begin{array}{l}\text { (Werner and } \\
\text { Richter 2007) }\end{array}$ & $\begin{array}{l}\text { (Rivela et al. 2006b; Xu } \\
\text { et al. 2008; González- } \\
\text { García et al. 2009b) }\end{array}$ \\
\hline Global warming & $\mathrm{kg} \mathrm{CO} \mathrm{Cq}_{2}$ & $\mathrm{~kg} \mathrm{CO}_{2} \mathrm{eq}$ & $\mathrm{kg} \mathrm{CO}$ eq & DALY \\
\hline Ozone layer depletion & $\mathrm{kg} \mathrm{CFC} 11 \mathrm{eq}$ & $\mathrm{kg} \mathrm{CFC} 11 \mathrm{eq}$ & $\mathrm{kg} \mathrm{CFC} 11 \mathrm{eq}$ & DALY \\
\hline Acidification & $\begin{array}{l}\mathrm{kg} \mathrm{SO} \mathrm{Sq}_{2} \\
\text { mole of } \mathrm{H}^{+} \text {eq }\end{array}$ & $\mathrm{kg} \mathrm{SO}_{2} \mathrm{eq}$ & $\mathrm{kg} \mathrm{SO}_{2} \mathrm{eq}$ & PAF $\mathrm{m}^{2}$ year \\
\hline Eutrophication & $\mathrm{kg} \mathrm{NO}_{3}$ eq & $\mathrm{kg} \mathrm{PO}_{4} \mathrm{eq}$ & $\mathrm{kg} \mathrm{PO}_{4} \mathrm{eq}$ & PAF $\mathrm{m}^{2}$ year \\
\hline Photochemical oxidant & $\mathrm{kg} \mathrm{C}_{2} \mathrm{H}_{4}$ eq & $\mathrm{kg} \mathrm{C}_{2} \mathrm{H}_{2}$ eq & $\mathrm{kg} \mathrm{C}_{2} \mathrm{H}_{4} \mathrm{eq}$ & $\mathrm{kg} \mathrm{C}_{2} \mathrm{H}_{4}$ eq \\
\hline Ecotoxicity & $\mathrm{m}^{3}$ in water & $\mathrm{kg} 1.4 \mathrm{DB}$ eq & PAF $\mathrm{m}^{2}$ year & PAF $\mathrm{m}^{2}$ year \\
\hline Human toxicity & $\mathrm{m}^{3}$ in air & $\mathrm{kg} 1.4 \mathrm{DB}$ eq & & \\
\hline Carcinogens & & & $\mathrm{kg} \mathrm{B}(\mathrm{a}) \mathrm{P}$ & DALY \\
\hline $\begin{array}{l}\text { Respiratory organics/ } \\
\text { inorganics }\end{array}$ & & & DALY & DALY \\
\hline Land use & & & & PDF $\mathrm{m}^{2}$ year \\
\hline Solid waste & $\mathrm{kg}$ & & $\mathrm{kg}$ & \\
\hline Abiotic resources depletion & & $\mathrm{kg} \mathrm{Sb}$ eq & & \\
\hline Energy resources & & & MJ LHV & MJ surplus \\
\hline
\end{tabular}

$D A L Y$ disability adjusted life years, $P D F$ potentially disappeared fraction, $P A F$ potentially affected fraction, $L H V$ lower heat value

Gasol et al. (2008) combined CML-2000 and Cumulative Energy Demand (CED) methods, Werner et al. (2007) combined Eco-indicator 95 and CED methods, and Solli et al. (2009) combined CML-2000 and characterization factors of Johansson et al. (2004), Hertwich et al. (2006)

indictor 99 do not cover solid waste as a separate impact category. This is because solid waste is, in these approaches, considered as a by-products entering a waste-treatment process or being recycled and therefore belonging to the technosphere (Klöpffer 2009).

EDIP-97, Eco-indicator 95, and Eco-indictor 99 approaches refrain from spatial differentiation (see Table 2). This implies that the studies did not consider the geographic variability of the potential impact assessed. The use of site generic characterization factors is only appropriate to evaluate potential environmental impacts for which the location of its perpetrator is unrelated. The relevance of the assessment of other potential environmental impacts may be affected by using site generic characterization methods because its occurrence is related to the location of the perpetrator. The use of a characterization methodology without spatial differentiation could lead to invalid results. The inclusion of geographical information in LCIA will increase the accordance between the potential impact predicted by LCA studies and the expected occurrence of actual potential impact (Potting and Hauschild 1997a; Potting and Hauschild 1997b). Potting et al. (1998) were the first to develop and calculate sophisticated characterization factors that establish the relation between the region of emission and its potential impact on the receiving environment. Recent LCIA approaches as EDIP2003 (Hauschild and Potting 2005) and CML-2000 (Guinée 2002) now include site-dependent characterization factors. Available sets of site-dependent factors unfortunately only cover Europe and North America (Potting and Hauschild 2006). Clearly, there is a need to elaborate practical models for the inclusion of spatial differentiation into LCIA for other continents, including Africa. Future research should focus on developing LCIAs geographically specific to continents, regional concerns, and those that are situation-dependent, to better reflect local variations for such potential impacts that are not global in nature. For the time being, Hauschild and Potting (2005) recommend using site-generic characterization factors for regions and continents not covered by site-dependent characterization factors.

Our review of LCIA approaches and characterization methods shows that CML-2000 is the most frequently used and also the most internationally accepted and recognized impact approach in LCAs of timber products. CML-2000 uses mid-point indicators that are relatively transparent in the underlying physical modeling. This study will therefore, as a starting-point, follow the CML2000 approach for our environmental impact assessment of the timber sector in Ghana but seeks to combine it with other approaches where relevant. 
3.3 Application of the relevant LCIA approach for LCA studies in the timber sector

This section applies CML-2000 to the LCI results of Eshun et al. (2010) for characterization of the impact categories of global warming, acidification, eutrophication, photochemical oxidant formation, and human toxicity. Table 3 provides the CML-2000 characterization factors used for each of these impact categories. Deviating from the recommendation of Hauschild and Potting (2005), we used the conventional characterization factors for acidification, i.e., alternative generic acidification potentials in Guinée (2002). This is because the site-generic factors in the baseline-approach are based on European data and considered not to adequately reflect the African situation. We therefore decided to use the conventional or alternative factors that quantify the maximum acidifying potential of the substances considered. Wood waste, which basically is an inventory item, is characterized by simply adding together the contributions to them. Characterization of biodiversity for the timber sector of Ghana is addressed at the end of this section.

Figure 1 presents the overall LCIA results for the total timber sector in Ghana. These results are below discussed per impact category separately.

Figure 2 presents the overall LCIA results for each of the three functional units (volume (cubic meters), mass (kilograms), and money (Euros)). The results for each impact category show, obviously in accordance with Eshun et al. (2010), their sensitivity for the choice of functional unit.
This indicates any policy choice for each impact category must consider a correct choice of functional units.

The total global warming impact from $\mathrm{CO}_{2}, \mathrm{CH}_{4}$, and $\mathrm{N}_{2} \mathrm{O}$ emissions amounted to approximately $765 \mathrm{kt} \mathrm{CO}_{2}$ equivalents per year (Table 4). Air-dried lumber contribute little (only $1 \%$ ) because its reliance on natural air for drying. Kiln-dried lumber, plywood, and veneer production lines were then the main contributors with a score of $30 \%$ each (see Table 4). The over-dependence on wood waste for drying wood product in the timber sector thus threatens the sustainability of Ghana's natural forest.

The total annual acidifying impact from $\mathrm{SO}_{2}$ and $\mathrm{NO}_{\mathrm{X}}$ amounted to $1,179 \mathrm{t} \mathrm{SO}_{2}$-equivalent per year (see Table 4). When the contributor of total acidifying impacts was considered, we found that kiln-dried lumber production contributed the largest proportion (i.e., 33\%). This high value is as a result of the intensity of the drying processes. Plywood production was second with $28 \%$ while furniture contributed only $12 \%$ (see Fig. 1) because of its lower fuel usage.

The total eutrophying impact amounted to $169 \mathrm{t} \mathrm{PO}_{4}$ equivalent per year (see Table 4). Kiln-dried lumber was the largest contributor with a share of $35 \%$. This is the result of the intensity of the kiln-drying processes. The least contributor is furniture production with a share of $11 \%$. This low eutrophying impact relates to the many manual activities at its final production stage.

The total potential impact of tropospheric ozone precursor compounds in the timber sector of Ghana amounted to about $1 \mathrm{kt}$ ethylene-equivalent per year (see

Table 3 Selected impact categories, LCIA method, and characterization factors applied to the timber sector of Ghana

\begin{tabular}{|c|c|c|c|c|c|}
\hline $\begin{array}{l}\text { Impact } \\
\text { category }\end{array}$ & Scale & $\begin{array}{l}\text { Examples of LCI data } \\
\text { (i.e., classification) }\end{array}$ & $\begin{array}{l}\text { Characterization } \\
\text { factor }\end{array}$ & $\begin{array}{l}\text { Description of } \\
\text { characterization factor }\end{array}$ & Reference \\
\hline $\begin{array}{l}\text { Global } \\
\text { warming }\end{array}$ & Global & $\begin{array}{l}\text { Carbon dioxide }\left(\mathrm{CO}_{2}\right) \\
\text { Methane }\left(\mathrm{CH}_{4}\right) \\
\text { Nitrous Oxide }\left(\mathrm{N}_{2} \mathrm{O}\right)\end{array}$ & $\begin{array}{l}1 \mathrm{~kg}=1 \mathrm{CO}_{2} \text { eq } \\
1 \mathrm{~kg}=21 \mathrm{CO}_{2} \text { eq } \\
1 \mathrm{~kg}=310 \mathrm{CO}_{2} \text { eq }\end{array}$ & $\begin{array}{l}\text { Converts LCI data to carbon } \\
\text { dioxide }\left(\mathrm{CO}_{2}\right) \text { equivalents } \\
\text { Note: global warming potentials } \\
\text { for } 100 \text { year potentials }\end{array}$ & $\begin{array}{l}\text { (Houghton } \\
\text { et al. 1996) }\end{array}$ \\
\hline Acidification & Regional & $\begin{array}{l}\text { Sulfur dioxide }\left(\mathrm{SO}_{2}\right) \\
\text { Nitrogen oxides }(\mathrm{NOx})\end{array}$ & $\begin{array}{l}1 \mathrm{~kg}=1 \mathrm{SO}_{2} \text { eq } \\
1 \mathrm{~kg}=0.7 \mathrm{SO}_{2} \text { eq }\end{array}$ & Converts LCI data to $\mathrm{SO}_{2}$ equivalents & $\begin{array}{l}\text { Heijungs et al. } \\
\text { (1992) }\end{array}$ \\
\hline Eutrophication & $\begin{array}{l}\text { Regional } \\
\text { Local }\end{array}$ & Nitrogen oxides (NOx) & $1 \mathrm{~kg}=1.3 \mathrm{PO}_{4} \mathrm{eq}$ & Converts LCI data to $\mathrm{PO}_{4}$ equivalents & $\begin{array}{l}\text { Heijungs et al. } \\
\text { (1992) }\end{array}$ \\
\hline $\begin{array}{l}\text { Photochemical } \\
\text { smog }\end{array}$ & Local & $\begin{array}{l}\text { Non-methane } \\
\text { hydrocarbon } \\
\text { (NMVOC) } \\
\text { Carbon mono-oxide (CO) } \\
\text { Methane }\left(\mathrm{CH}_{4}\right) \\
\text { Nitrogen oxides (NOx) }\end{array}$ & $\begin{array}{l}1 \mathrm{~kg}=0.416 \mathrm{C}_{2} \mathrm{H}_{2} \text { eq } \\
1 \mathrm{~kg}=0.027 \mathrm{C}_{2} \mathrm{H}_{2} \text { eq } \\
1 \mathrm{~kg}=0.006 \mathrm{C}_{2} \mathrm{H}_{2} \text { eq } \\
1 \mathrm{~kg}=0.028 \mathrm{C}_{2} \mathrm{H}_{2} \text { eq }\end{array}$ & $\begin{array}{l}\text { Converts LCI data to ethylene } \\
\text { equivalents }\end{array}$ & (Guinée et al. 2000) \\
\hline Human toxicity & Local & $\begin{array}{l}\text { Sulfur dioxide (SO2) } \\
\text { Nitrogen oxides (NOx) }\end{array}$ & $\begin{array}{l}1 \mathrm{~kg}=0.096 \mathrm{C}_{6} \mathrm{H}_{4} \mathrm{C}_{\mathrm{i} 2} \text { eq } \\
1 \mathrm{~kg}=1.2 \mathrm{C}_{6} \mathrm{H}_{4} \mathrm{C}_{\mathrm{i} 2} \text { eq }\end{array}$ & $\begin{array}{l}\text { Converts LCI data to dichlorobenzene } \\
\left(\mathrm{C}_{6} \mathrm{H}_{4} \mathrm{C}_{\mathrm{i} 2}\right) \text { equivalents }\end{array}$ & CML (2002) \\
\hline Wood waste & Local & $\begin{array}{l}\text { Quantity of wood waste } \\
\text { generated }\end{array}$ & $\mathrm{kg}$ of wood waste produced & $\begin{array}{l}\text { Converts LCI data to } \\
\text { the quantity of wood } \\
\text { wastes output }\end{array}$ & $\begin{array}{l}\text { (Udo de Haes } \\
\text { et al. 1999) }\end{array}$ \\
\hline
\end{tabular}


Fig. 1 Relative contribution by different wood production lines to the total environmental impact of the timber sector of Ghana



Table 4). Kiln-dried lumber production had the highest tropospheric ozone precursor's impact with a share of 34\%. The second highest tropospheric ozone precursor's impact was plywood production with a share of $31 \%$. Airdried lumber production was the least contributor (see Fig. 1).

The total potential impacts of human toxicity compounds in the Ghanaian timber sector amounted to about $58 \mathrm{tC}_{6} \mathrm{H}_{4} \mathrm{Cl}_{2}$-equivalent per year (see Table 4). Kiln-dried lumber contributed the highest potential impact with a share of $35 \%$. The second contributor to human toxicity impact was plywood production with a share of $26 \%$ (see Fig. 1).
The total wood wastes of the timber industry, as already quantified in Eshun et al. (2010), amount to $288 \mathrm{kt}$ per year (see Table 4). This value does not include the amount generated at the forestry subsystem because of lack of appropriate data. The contributions to wood waste by the various production lines are illustrated in Fig. 1. Kiln-dried lumber contributed to the highest production of wood waste with a share of $35 \%$. Veneer product is the least contributor to wood waste in the timber industry in Ghana with a share of $4 \%$.

A comprehensive LCA is supposed to include all relevant environmental concerns. For the timber sector, biodiversity is a major concern because of the land degradation by deforestation and desertification. Unfortunately, biodiversity

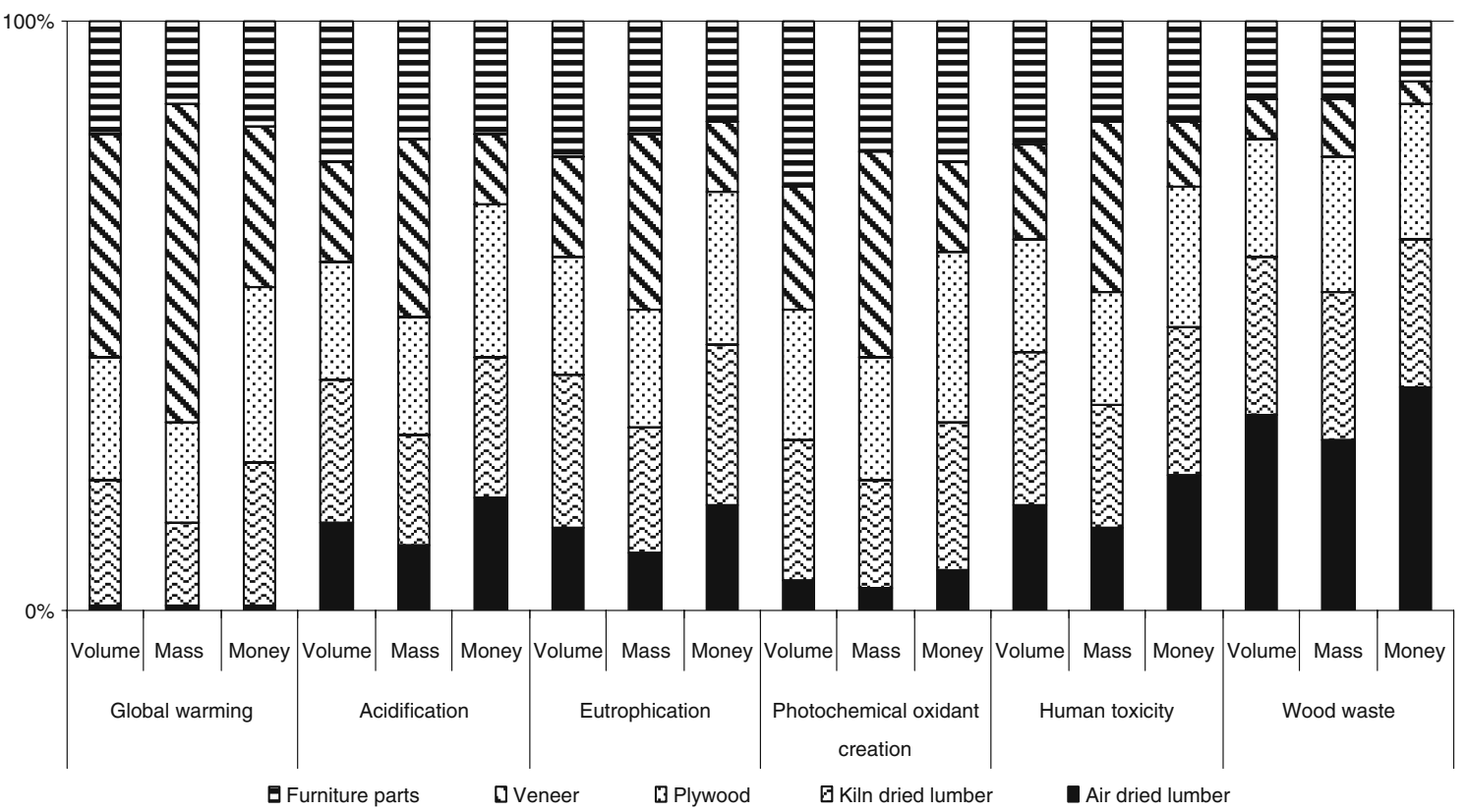

Fig. 2 Influence of functional unit on environmental impact results for five major production lines in Ghana's timber sector to Volume (cubic meters), mass (kilograms), and money (Euros) 
Table 4 Overview of the total environmental impact contributions from the five production lines of the timber sector in Ghana

\begin{tabular}{|c|c|c|c|c|c|c|c|}
\hline \multirow[t]{2}{*}{ Impact Category } & \multirow[t]{2}{*}{ Emissions } & \multicolumn{5}{|l|}{ Products } & \multirow[t]{2}{*}{ Total } \\
\hline & & $\begin{array}{l}\text { Air-dried } \\
\text { lumber }\end{array}$ & $\begin{array}{l}\text { Kiln-dried } \\
\text { lumber }\end{array}$ & Plywood & Veneer & $\begin{array}{l}\text { Furniture } \\
\text { parts }\end{array}$ & \\
\hline \multirow[t]{3}{*}{ Global warming ( $\mathrm{kt} \mathrm{CO}_{2}-\mathrm{eq} /$ year) } & $\mathrm{CO}_{2}$ & 8 & 219 & 223 & 219 & 77 & 745 \\
\hline & $\mathrm{CH}_{4}$ & 0 & 6 & 3 & 2 & 1 & 12 \\
\hline & $\mathrm{N}_{2} \mathrm{O}$ & 0 & 3 & 2 & 2 & 1 & 8 \\
\hline Total & & 8 & 228 & 229 & 222 & 78 & 765 \\
\hline Percent & & 1 & 30 & 30 & 29 & 10 & 100 \\
\hline \multirow[t]{2}{*}{ Acidification ( $\mathrm{t} \mathrm{SO}_{2}-\mathrm{eq} /$ year) } & $\mathrm{SO}_{2}$ & 53 & 76 & 50 & 18 & 25 & 222 \\
\hline & $\mathrm{NO}_{\mathrm{X}}$ & 117 & 320 & 278 & 130 & 112 & 957 \\
\hline Total & & 170 & 396 & 328 & 148 & 137 & 1,179 \\
\hline Percent & & 14 & 33 & 28 & 13 & 12 & 100 \\
\hline Eutrophication ( $\mathrm{t} \mathrm{PO}_{4}-\mathrm{eq} /$ year) & $\mathrm{NO}_{\mathrm{X}}$ & 21 & 58 & 47 & 22 & 19 & 169 \\
\hline Total & & 21 & 58 & 47 & 22 & 19 & 169 \\
\hline Percent & & 13 & 35 & 28 & 13 & 11 & 100 \\
\hline \multirow{4}{*}{$\begin{array}{l}\text { Photochemical oxidation } \\
\text { formation }\left(\mathrm{t} \mathrm{C}_{2} \mathrm{H}_{2}-\mathrm{eq} / \text { year }\right)\end{array}$} & NMVOC & 53 & 119 & 72 & 35 & 62 & 305 \\
\hline & $\mathrm{CO}$ & 0 & 238 & 247 & 130 & 84 & 699 \\
\hline & $\mathrm{CH}_{4}$ & 0 & 2 & 1 & 0 & 0 & 3 \\
\hline & $\mathrm{NO}_{\mathrm{X}}$ & 5 & 13 & 10 & 5 & 4 & 37 \\
\hline Total & & 58 & 372 & 330 & 170 & 150 & 1,080 \\
\hline$\%$ & & 5 & 34 & 31 & 16 & 14 & 100 \\
\hline \multirow[t]{2}{*}{ Human toxicity $\left(\mathrm{t}_{6} \mathrm{H}_{4} \mathrm{Cl}_{2}-\mathrm{eq} /\right.$ year) } & $\mathrm{SO}_{2}$ & 5 & 7 & 5 & 2 & 2 & 21 \\
\hline & $\mathrm{NO}_{\mathrm{X}}$ & 5 & 13 & 10 & 5 & 4 & 37 \\
\hline Total & & 10 & 20 & 15 & 7 & 6 & 58 \\
\hline Percent & & 17 & 35 & 26 & 12 & 10 & 100 \\
\hline Wood waste (kt/year) & & 82 & 101 & 76 & 10 & 19 & 288 \\
\hline Percent & & 29 & 35 & 26 & 4 & 6 & 100 \\
\hline
\end{tabular}

is one of the least mature impact categories in LCA approaches. There have been several attempts to develop biodiversity impact indicators based on biodiversity concepts such as species richness (Weidema and Lindeijer 2001), ecosystem dynamics (Wagendorp et al. 2006), threats to species (Hawthorne and Abu-Juam 1995; Müller-Wenk 1998), and habitat protection (Schenck 2001). All these indicators exhibit space-dependent and non-linear behavior, reflecting the spatial patterns of biodiversity. Developing biodiversity-loss indicators for LCA is still in its early stage (Lindeijer et al. 2002). We therefore decided to stick for this impact category to land use as quantified by Eshun et al. (2010). Eshun et al. quantified land use, which is basically an inventory item and not an impact category, as the area of tropical forest harvested.

\subsection{Correlation analysis between different environmental impacts}

The LCIA phase was initially introduced in LCA to facilitate interpretation of its results by reducing the large number of inventory items to a limited number of impact categories (Potting et al. 1998). Eshun et al. (2010) quantified nine inventory items, whereas our LCIA here covers seven impact categories. Our LCIA thus hardly facilitates interpretation by its number of impact categories that is roughly similar to the number of inventory items in Eshun et al. (2010).

The importance of LCIA gradually moved to enhancing the environmental relevance of LCA as a tool when characterization methodology evolved. The above LCIA results quantify the potential environmental impact of the timber sector activities to the environment. This LCIA results give insight on how harmful the timber sector activities affect the environment as compared with Eshun et al. (2010) which just quantify only interactions between processes and the environment.

From the results, the enormous amounts of wood waste are a direct result of an inefficient use of the forest resources and therewith form a major driver of biodiversity loss in the Ghana timber sector. In other words, we consider the amount of waste wood in the timber sector of Ghana to adequately reflect biodiversity loss in Ghana. The other 
impact categories in our LCIA are more indirectly related to wood wastes. We therefore performed a simple correlation and regression analysis to learn whether wood wastes may function as a reasonable single indicator for land use as proxy for biodiversity loss and the other impact categories as well. This would enormously simplify a follow-up study in which we intend to explore environmental improvement options for economic activities in the timber sector in Ghana.

The correlation analysis was performed by statistically verifying the correlation between wood wastes land use and the other five selected potential environmental impact results. The contributions of each of the five production lines to wood wastes were correlated with their contributions to each of the other impact categories to see if some relationship exists. The variance and the coefficient of determination $R^{2}$ values were then calculated. This was to enable the researcher to understand the major contributor to the number of environmental problems in the timber sector of Ghana and to further carry out future improvement research if any.

Figure 3 presents the results of the correlation analysis. The results indicated that wood waste correlated positive between land use and the other five potential impacts results. The correlation between wood waste and land use were the strongest correlation with $R^{2}$ value of 0.9 . It can be concluded that wood waste production is major driving force for biodiversity loss and a sufficiently good single indicator for all other potential environmental impact in the timber sector of Ghana. This correlation will be very useful for preliminary screening of potential environmental impacts, waste minimization analysis, or an evaluation of emerging technologies at early stages of decision making in the timber sector of Ghana.

\section{Discussion}

Our LCIA for the timber sector in Ghana uses CML-2000 for the larger part of the selected impact categories. The impact categories in CML-2000 take their basis in the environmental problems in western countries. Also, the CML-2000 methodologies for characterizing those potential impacts are based on how these problems manifest themselves in the western world (SETAC 1994; Alsema 2000; Tukker 2000; Brentrup et al. 2004; Pennington et al. 2004a). In particular, the characterization methodologies for different impact categories in CML-2000 (and other LCIA approaches in Section 3.2) may not be necessarily relevant to African tropical environmental conditions, and particularly not for the timber sector in Ghana. This situation hampers the reliability of our LCIA and points to a serious research gap in LCIA development in general.
The integrated coverage of a broad range of impact categories in LCA studies is very important for, in particular, African tropical countries for several reasons. We consider the preliminary selection of impact categories in Section 3.2 as relevant for the African continent (but not exhaustive).

Firstly, Africa is a developing continent and its quest to catch up with the developed economies is likely to add up to an increasing energy use and related greenhouse gas emissions (IPCC 2007b). This development will enhance climate change. Climate change will leads to more increase forest fires, biodiversity loss, increased adverse health impacts from heat-related mortality, pollution, and shifts in infectious diseases. Africa is likely to be hardest hit by the global warming impact because of its vulnerability and adaptive capacity (IPCC 2007b).

Secondly, the timber sector in Africa, particularly Ghana, generates acidifying and eutrophying emissions through activities such as timber harvesting, transportation, and production processes. These emissions may be detrimental to human and aquatic life, since most people in Africa have limited access to portable drinking water and depend heavenly on untreated river water. Moreover, Africa, particularly, Ghana's, current developmental agenda is likely to contribute to acidification, eutrophication, and photochemical oxidation problems in the future.

Thirdly, Africa has the highest deforestation and biodiversity loss rate of the world's regions (FAO 2005). Ghana loses an estimated $340 \mathrm{~km}^{2}$ of its forests annually (Eshun et al. 2010). According to Millennium Ecosystem Assessment (2005) and IPCC (2007a), future climate change is likely to have significant repercussion for biodiversity through existing threats like tropical deforestation and unstained timber harvesting. According to Dionco-Adetayo (2001), for $1 \mathrm{~m}^{3}$ of tree harvested in a tropical forest, about $0.8 \%$ goes to waste. These are in the form of damaged residuals $(50 \%)$, abandoned $\operatorname{logs}(3.75 \%)$, tops and branches $(33.75 \%)$, stumps (10\%), and butt trimmings (2.5\%). In Ghana's tropical rain forest, wood waste is one of the most abundant, cost-effective, and environmentally friendly biomass resource, but this waste is either left in forests (for firewood) or landfills, or sent to boilers to generate heat and steam for drying wood products. This leads to air pollutants and other environmental problems. The environmental, economical, and social considerations for adding value to wood waste far outweigh the use of wood waste as firewood or fuel in drying wood (Rivela et al. 2006a). In order to sustainably manage Ghana's timber sector, wood waste problems have to be addressed. In LCA, wood waste is generally not addressed as an impact category.

Fourthly, land degradation is also a serious issue in Africa (UNEP 2002). Erosion as a result of sand and gravel mining, excessive farming, and mining in forest reserves 

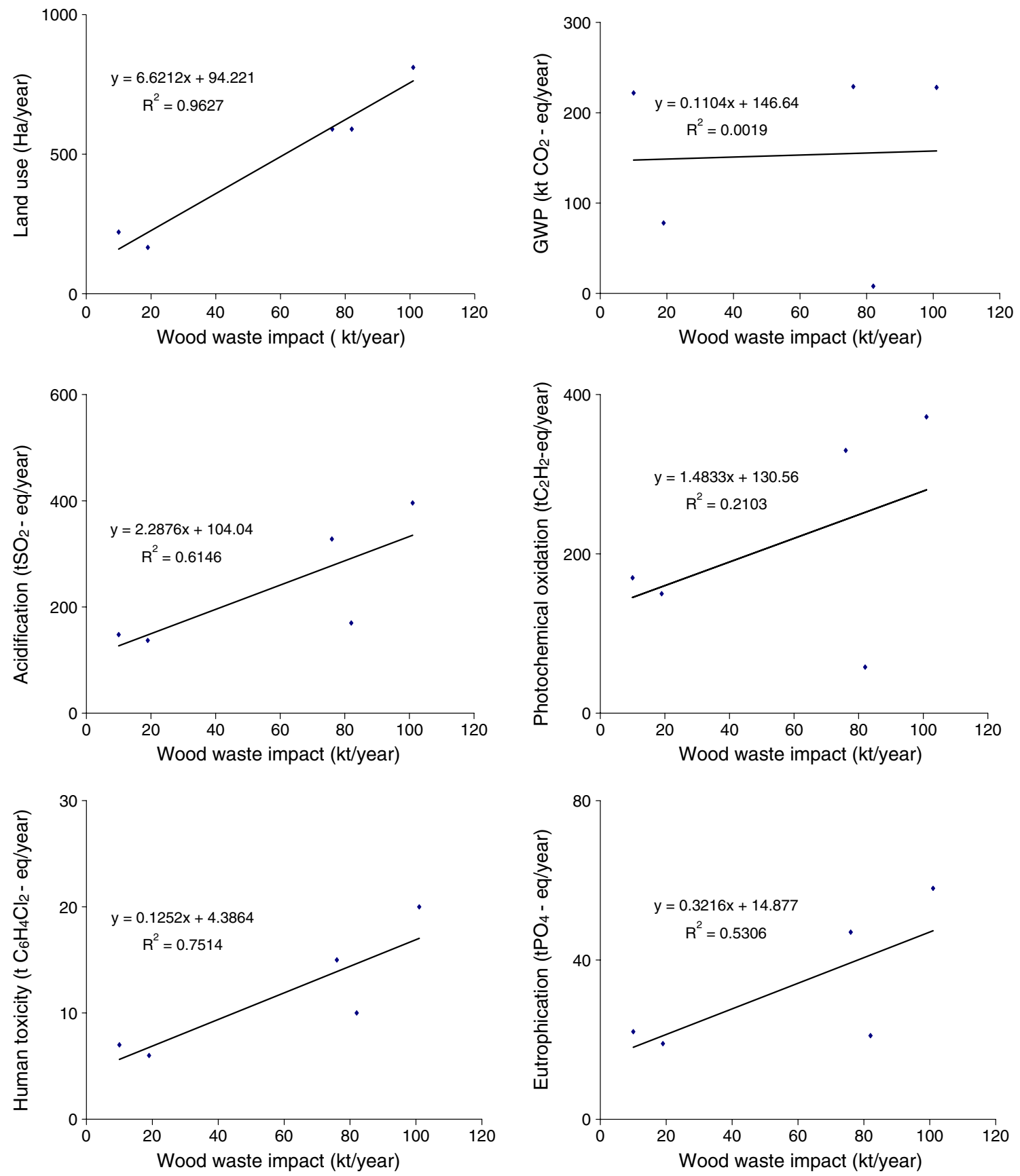

Fig. 3 Correlation analysis between the contributions of each of the five production lines to wood waste impact and land use as proxy for biodiversity loss and the other five environmental impacts such as

global warming, acidification, eutrophication, photochemical oxidation formation, and human toxicity in the timber sector of Ghana

are common land degradation problems in Africa (UNEP 2007). Addressing the issue of land degradation through the use of LCA in Africa is a vital key to help Africa reduce poverty and achieve some of its targets as set out under the Millennium Development Goals.

Our review of LCIA approaches and characterization methods confirms that most LCIA in LCA take their basis in the environmental problems in western countries and their characterization methodologies relating to how these prob-

lems manifest themselves in the western world. Available sets of site-dependent factors unfortunately only cover Europe and North America (Potting and Hauschild 2006). The characterization methodologies for different impact categories may not be necessarily relevant to African environmental conditions, and particularly not for the timber sector in Ghana. This review shows that there is a need to elaborate practical models for the inclusion of spatial differentiation into LCIA for other continents, including Africa. According to the 
evaluation of LCIA approaches and characterization methods, CML-2000 is the most frequently used and also the most internationally accepted and recognized impact approach in LCAs of timber products. CML-2000 uses midpoint indicators that are relatively transparent in the underlying physical modeling. This study, therefore, as a starting-point, applies CML-2000 to the LCI results of Eshun et al. (2010) for characterization of the impact categories of global warming, acidification, eutrophication, photochemical oxidant formation, and human toxicity. We also performed a correlation and regression analysis to learn whether wood wastes may function as a reasonable single indicator for land use as proxy for biodiversity loss and the other five selected impact categories. The correlation analysis indicated that wood waste is indeed strongly correlated with land use as proxy for biodiversity loss, and also positively correlated with the other five potential impacts results. It can be concluded that wood waste production is major driving force for biodiversity loss and a sufficiently good single indicator for all other potential environmental impact in the timber sector of Ghana. This correlation will be very useful for preliminary screening of environmental impacts, waste minimization analysis, or an evaluation of emerging technologies at early stages of decision making in the timber sector of Ghana.

Finally, it is therefore critical that this study and the previous LCI paper, Eshun et al. (2010) are pioneering a field not yet explored, since the correct impact indicators are not yet developed or adapted to tropical conditions. The development of life cycle impact assessment approaches in the tropics may be the start of a never-ending journey in LCA research in Africa.

When a proper LCIA approach is available for Africa, the improved quality of LCA results may better serve as an investment baseline for understanding industrial and individual company changes. It will also serve as a comparison tool for industry improvement and a benchmark against competing products and materials. In addition, it will provide tools for the corrugated industry to use in performing consistent calculations irrespective of the country. Sustainability and LCIA approaches are strategic bridges to prioritizing and implementing sustainable initiatives projects that will create value for key stakeholders in the timber sector of Africa, particularly Ghana.

\section{Conclusions}

Most LCIA approaches are developed for western countries. We reviewed their relevance for the timber sector in Ghana and applied the most relevant on to the results of an earlier LCI from Eshun et al. 2010. Our study now provides preliminary LCIA results and primary data unique for tropical LCA research in Africa, particularly Ghana.
The LCIA results quantified global warming, acidification, eutrophication, photochemical oxidant formation, and human toxicity impacts from timber sector activities. From the study, the enormous amounts of wood waste generated are a direct result of an inefficient use of the forest resources, and therewith form a major driver of biodiversity loss in the Ghana timber sector. In other words, we consider the amount of waste wood in the timber sector of Ghana to adequately reflect biodiversity loss in Ghana. The other impact categories in our LCIA are more indirectly related to wood wastes. We performed a simple correlation and regression analysis to learn whether wood wastes may function as a reasonable single indicator for land use as proxy for biodiversity loss and the other five selected impact categories. The correlation analysis indicated that wood waste is indeed strongly correlated with land use as proxy for biodiversity loss and also positively correlated with the other five potential impacts results. It can be concluded that wood waste production is major driving force for biodiversity loss and a sufficiently good single indicator for all other potential environmental impact in the timber sector of Ghana. This correlation will be very useful for preliminary screening of potential environmental impacts, waste minimization analysis, or an evaluation of emerging technologies at early stages of decision making in the timber sector of Ghana.

The generic approach that was used in this study helped improve the basis for decision making in the timber sector of Ghana and clearly showed that LCA is a powerful tool for the assessment of environmental impacts of the timber sector in developing countries. However, there is an urgent need to include spatial differentiation into the LCIAs for developing continents, like Africa. Relevant impact categories, LCIA approaches, and characterization methods to achieve this have to be further developed to address regional concerns and situations and to better reflect local variations. If used, we can then make a strong contribution to sustainability goals in Ghana and Africa.

Open Access This article is distributed under the terms of the Creative Commons Attribution Noncommercial License which permits any noncommercial use, distribution, and reproduction in any medium, provided the original author(s) and source are credited.

\section{References}

Aldentun Y (2002) Life cycle inventory of forest seedling production-from seed to regeneration site. J Cleaner Prod 10:47-55

Alsema E (2000) Environmental Life Cycle Assessment of Solar Home Systems. Department of Science Technology and Society. Utrecht University, Utrecht, p 89

Awanyo L (2007) A Janus-faced biodiversity change and the partiality of ecological knowledge in a world biodiversity hotspot in Ghana: implications for biodiversity rehabilitation. Geoforum 38:739-751 
Barnthouse L, Fava J, Humphreys K, Hunt R, Laibson L, Noesen S, Owens J, Todd J, Vigon B, Weitz K, Young J (1997) Life-cycle impact assessment: the state-of-the-art. Report of the SETAC lifecycle assessment (LCA) Impact Assessment Working group, SETAC LCA Advisory Group

Berkhout F (1995) Life cycle assessment and industrial innovation, The 1995 eco-management and auditing conference Leeds 50-64

Brentrup F, Küsters J, Kuhlmann H, Lammel J (2004) Environmental impact assessment of agricultural production systems using the life cycle assessment methodology I. Theoretical concept of a LCA method tailored to crop production. Europ J Agronomy 20:247-264

CML (2002) Impact assessment spreadsheet version 2.6. Center of Environmental Science, Lieden University, The Netherlands

Daniel SE, Pappis CP (2008) Application of LCIA and comparison of different EOL scenarios: The case of used lead-acid batteries. Resourc Conserv Recycl 52:883-895

Dionco-Adetayo EA (2001) Utilization of wood wastes in Nigeria: a feasibility overview. Technovation 21:55-60

Dubreuil A, Gaillard G, Müller-Wenk R (2007) Key elements in a framework for land use impact assessment within LCA. Int J Life Cycle Assess 12:5-15

Eshun JF, Potting J, Leemans R (2010) Inventory analysis of the timber industry in Ghana. Int J Life Cycle Asees 15:715-725

FAO (2005) Global forest resources assessment 2005. Food and Agriculture Organization of the United Nations, Rome

Gasol C, Farreny T, Gabarrell X, Rieradevall R (2008) Life cycle assessment comparison among different reuse intensities for industrial wooden containers. Int J Life Cycle Assess 13:421-431

Goedkoop M (1995) The Eco-indicator 95. Final Report, NOH report 9523, Pre Consultants, Amersfoort, The Netherlands

Goedkoop M, Spriensma R (2000) The Ecoindicator'99: a damage oriented method for life cycle impact assessment: methodology report. Pré Consultants BV, Amersfoort: The Netherlands

González-García S, Berg S, Feijoo G, Moreira M (2009a) Environmental impacts of forest production and supply of pulpwood: Spanish and Swedish case studies. Int J Life Cycle Assess 14:340-353

González-García S, Berg S, Feijoo G, Moreira MT (2009b) Comparative environmental assessment of wood transport models: a case study of a Swedish pulp mill. Sci Total Environ 407:3530-3539

González-García S, Feijoo G, Widsten P, Kandelbauer A, Zikulnig-Rusch E, Moreira M (2009c) Environmental performance assessment of hardboard manufacture. Int J Life Cycle Assess 14:456-466

Goyal SK, Deshpande VA (2001) Comparison of weight assignment procedures in evaluation of environmental impact. Environ Impact Assess Rev 21:553-563

Guinée JB (2002) Handbook on life cycle assessment. Operational guide to the ISO standard. Kluwer Academic, Dordrecht

Guinée JB, Heijungs R, Udo de Haes HA, Huppes G (1993a) Quantitative life cycle assessment of products, part 2: classification, validation and improvement analysis. J Cleaner Prod 1:8191

Guinée JB, Udo de Haes HA, Huppes G (1993b) Quantitative life cycle assessment of products, part 1: goal definition and inventory. J Cleaner Prod 1:3-13

Guinée JB, Gorree R, Heijungs G, Huppes R, Kleijn R, Udo de Haes HA (2000) Environmental life cycle assessment: backgrounds. Centre of Environmental Science (CML). Leiden University, Leiden

Guinée JB et al. (2001) An operation guide to the ISO-Standards-part 3: scientific backgrounds, CML, Leiden University

Hauschild MZ, Potting J (2005) Spatial differentiation in life cycle impact assessment-the EDIP2003 methodology. Environmental News no. 80. The Danish Ministry of the Environment, Environmental Protection Agency, Copenhagen

Hawthorne WD, Abu-Juam M (1995) Forest Protection in Ghana. IUCN, Gland, p 202
Heijungs R, Guinée JB, Huppes G, Lankreijer RM, Udo de Haes HA, Wegener Sleeswijk A, Ansems AMM, Eggels PG, Van Duin R, De Goede HP (1992) Environmental life cycle assessment of products, guidelines and backgrounds. Center of Environmental Science (CML) (NOH report 9266 and 9267), Leiden

Hertwich EG, Mateles SF, Pease WS, McKone TE (2006) An update of the human toxicity potential with special consideration of conventional air pollutants. IndEcol Working Papers 1/2006, Norwegian University of Science and Technology, Norway, 2006. www.ntnu.no/oko

Hischier R, Althaus H-J, Werner F (2005) Developments in wood and packaging materials life cycle inventories in ecoinvent (9 pp). Int J Life Cycle Assess 10:50-58

Houghton JT, Meira Filho LG, Callander BA, Harris N, Kattenberg A, Maskell K (1996) Climate Change 1995: The Science of Climate Change. Cambridge University Press, Cambridge

ILCD (2010) International Reference Life Cycle Data System (ILCD) handbook. General guide for life cycle assessment - detailed guidance - first edition. European Commission Joint Research Centre, Institute for Environment and Sustainability

IPCC (2007a) Climate Change 2007: Impacts, adaptation and vulnerability: summary for policymakers. Working Group II Contribution to the Intergovernmental Panel on Climate Change Fourth Assessment Report, Geneva

IPCC (2007b) Intergovernmental Panel on Climate Change. Fourth assessment report on climate change 2007: Climate Change Impacts, Adaptation and Vulnerability

ISO-14044 (2006) Environmental management—-life cycle assessment -requirements and guidelines

Johansson L, Leckner B, Gustavsson L, Cooper D, Tullin C, Potter A (2004) Emission characteristics of modern and old-type residential boilers fired with wood logs and wood pellets. Atmos Environ 38:183-4195

Johnson L, Lippke J, Marshall J, Comnick J (2005) Life-cycle impacts of forest resource activities in the Pacific Northwest and the Southeast United States. Wood Fiber Sci 37:30-46

Khoo H, Tan T, Sagisaka M (2008) Utilization of woody biomass in Singapore: technological options for carbonization and economic comparison with incineration. Int J Life Cycle Assess 13:312-318

Klöpffer W (2009) Experiences with the critical review process of aluminium LCI data. Int J Life Cycle Assess 14:45-51

Lindeijer E, Müller-Wenk R, Steen B (2002) Impact Assessment of Resources and Land Use. In: Finnveden G, Goedkoop M, Hauschild M, Hertwich EG, Hofstetter P, Jolliet O, Klöpffer W, Krewitt W, Lindeijer EW, Müller-Wenk R, Olsen SI, Pennington DW, Potting J, Steen B, Udo de Haes HA (eds) Life Cycle Impact Assessment Striving Towards Best Practice. SETAC, Pensacola, USA, pp 11-64

Lindholm EL, Berg I (2005) Energy use in Swedish forestry in 1972 and 1997. J Forest Eng 16:27-37

Michelsen O (2008) Assessment of land use impact on biodiversity. Int J Life Cycle Assess 13:22-31

Michelsen et al (2008) Environmental impact and added value in forestry operations in Ghana. Industrial Ecol 12

Millennium Ecosystem Assessment (2005) Millennium Ecosystem Assessment, Ecosystems and Human Well-Being: Biodiversity Synthesis, Published by World Resources Institute, Washington, $\mathrm{DC}$

Milota MR, West CD, Hartley ID (2005) Gate-to-gate life-cycle inventory of softwood lumber production. Wood and Fiber Science 37:47-57

Müller-Wenk R (1998) Land use-the main threat to species. How to include land use in LCA Discussion Paper No. 064, Institut für Wirtschaft und Ökologie, Universität St. Gallen, Switzerland, St. Gallen

Nebel B, Zimmer B, Wegener G (2006) Life cycle assessment of wood floor coverings - a representative study for the German flooring industry. Int J Life Cycle Assess 11:172-182 
NEPP (1989) National Environmental Policy Plan: to choose or to lose. SDU-Uitgevery, The Hague (the Netherlands), $257 \mathrm{p}$

Pennington DW, Potting J, Finnveden G, Lindeijer E, Jolliet O, Rydberg T, Rebitzer G (2004) Life cycle assessment part 2: current impact assessment practice. Environ Int 30:721-739

Petersen AK, Solberg B (2005) Environmental and economic impacts of substitution between wood products and alternative materials: a review of micro-level analyses from Norway and Sweden Forest policy and Economics. pp 249-259

Potting J, Hauschild M (1997a) Predicted environmental impact and expected occurrence of actual environmental impact. Part1: the linear nature of environmental impact from emissions in life cycle assessment. Int J Life Cycle Assess 2:171-177

Potting J, Hauschild M (1997b) Predicted environmental impact and expected occurrence of actual impact: Part 2. Spatial differentiation in life cycle assessment via the site-dependent characterization of environmental impact from emissions. Int $\mathrm{J}$ Life Cycle Assess 2:209-216

Potting J, Hauschild M (2006) Spatial differentiation in life cycle impact assessment. Int J Life Cycle Assess 11:11-13

Potting J, Schöpp W, Blok K, Hauschild M (1998) Site-dependent life cycle impact assessment of acidification. J Ind Ecol 2:63-87

Puettmann ME, Wilson JB (2005) Life cycle analysis of wood products cradle to gate LCI of residential wood building materials. Wood Fiber Sci 37:18-22

Richter J, Sell J (1993) Life-cycle analysis: a useful approach to promote wood as a construction material. Wood Design Focus 4:14-17

Rivela B, Hospido A, Moreira T, Feijoo G (2006a) Life cycle inventory of particleboard: a case study in the wood sector. Int J Life Cycle Assess 11:106-113

Rivela B, Moreira MT, Muñoz I, Rieradevall J, Feijoo G (2006b) Life cycle assessment of wood wastes: a case study of ephemeral architecture. Sci Total Environ 357:1-11

Rivela B, Moreira M, Feijoo G (2007) Life cycle inventory of medium density fibreboard. Int J Life Cycle Assess 12:143-150

Schenck RC (2001) Land use and biodiversity indicators for life cycle impact assessment. Int J Life Cycle Assess 6:114-117

SETAC (1994) Society of Environmental Toxicology and Chemistry (SETAC), life cycle assessment data quality: a conceptual framework. SETAC and SETAC Foundation for Environmental Education, Inc, Washington DC
Solli C, Reenaas M, Strømman A, Hertwich E (2009) Life cycle assessment of wood-based heating in Norway. The Int J Life Cycle Assess 14:517-528

Tukker A (2000) Life cycle assessment as a tool in environmental impact assessment. Environ Impact Assess Rev 20:435-456

Udo de Haes HA, Jolliet O, Finnveden G, Hauschild M, Krewitt W, Müller-Wenk R (1999) Best available practice regarding impact categories and category indicators in life cycle impact assessment. Part I. Int J Life Cycle Assess 4:66-74

Udo de Haes HA, Finnveden G, Goedkoop M, Hauschild M, Hertwich EG, Hofstetter P, Jolliet O, Klöpffer W, Krewitt W, Lindeijer E, Müller-Wenk R, Olsen SI, Pennington DW, Potting J, Steen B (2002) Life-Cycle Impact Assessment: Striving Towards Best Practice. SETAC Press, Pensacola. ISBN 1-880611-54-6

UNEP (2002) Africa environment outlook: past, present and future perspectives. UNEP (2002b). Africa Environment Outlook: Past, Present and Future Perspectives

UNEP (2007) United Nations Environment Programme. Global Environment Outlook (GEO-4): Environment for Development (e-book)

Wagendorp T, Gulinck H, Coppin P, Muys B (2006) Land use impact evaluation in life cycle assessment based on ecosystem thermodynamics. Energy 31:112-125

Weidema BP, Lindeijer E (2001) Physical impacts of land use in product life cycle assessment Final report of the EURENVIRONLCAGAPS sub-project on land use. Technical University of Denmark, Lyngby

Wenzel H, Hauschild M, Alting L (1997) Environmental assessment of products. Volume 1: methodology, tools and case studies in product development. Chapman \& Hall, Kluwer Academic Publishers, London

Werner F, Richter K (2007) Wooden building products in comparative LCA. Int J Life Cycle Assess 12:470-479

Werner F, Althaus H-J, Richter K, Scholz R (2007) Post-consumer waste wood in attributive product LCA. The Int J Life Cycle Assess 12:160-172

Wilson J, Sakimoto E (2005) Gate-to-gate life-cycle inventory of softwood plywood production. Wood Fiber Sci 37:58-73

Xu X, Jayaraman K, Morin C, Pecqueux N (2008) Life cycle assessment of wood-fibre-reinforced polypropylene composites. J Mater Process Tech 198:168-177 